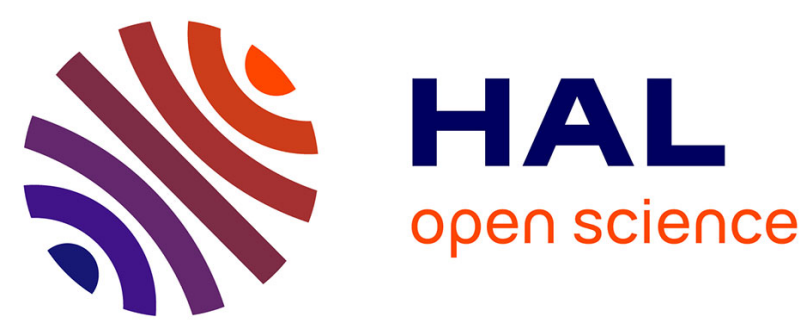

\title{
Comparison of Two Permeation Test Benches and of Two Determination Methods for Darcy's and Forchheimer's Permeabilities
}

Nicolas Gascoin, Guillaume Fau, Philippe Gillard, Markus Kuhn, Marc Bouchez, Johan Steelant

\section{To cite this version:}

Nicolas Gascoin, Guillaume Fau, Philippe Gillard, Markus Kuhn, Marc Bouchez, et al.. Comparison of Two Permeation Test Benches and of Two Determination Methods for Darcy's and Forchheimer's Permeabilities. Journal of Porous Media, 2012, 15 (8), pp.705-720. hal-00868691

\section{HAL Id: hal-00868691 https://hal.science/hal-00868691}

Submitted on 1 Oct 2013

HAL is a multi-disciplinary open access archive for the deposit and dissemination of scientific research documents, whether they are published or not. The documents may come from teaching and research institutions in France or abroad, or from public or private research centers.
L'archive ouverte pluridisciplinaire HAL, est destinée au dépôt et à la diffusion de documents scientifiques de niveau recherche, publiés ou non, émanant des établissements d'enseignement et de recherche français ou étrangers, des laboratoires publics ou privés. 
Comparison of Two Permeation Test Benches and of Two Determination Methods for Darcy's and Forchheimer's Permeabilities.

Nicolas Gascoin ${ }^{1}$, Guillaume Fau, Philippe Gillard PRISME, IUT Bourges, 63, avenue de Lattre de Tassigny - 18000 Bourges, France

Markus Kuhn

German Aerospace Center, Pfaffenwaldring 38-40, 70569 Stuttgart, Germany

Marc Bouchez

MBDA-France, 18 rue Le Brix - 18000 Bourges, France

and

Johan Steelant

European Space Research and Technology Centre, Keplerlaan 1, 2201 AZ Noordwijk, The

Netherlands

The thermal load protection of hypersonic and space vehicle structures can be achieved by either passive or active methods, such as ablative materials or active cooling. For the latter, porous Ceramic Matrix Composite media offer a possibility to exploit thermal protection by means of transpiration cooling due to their higher permeability. One of the related key issues is the determination of permeability parameters such as the Darcy's and Forchheimer's terms. The present paper aims at proposing an analytical and applied comparison of two of them (one based on the international norm ISO4022 and one derived for compressible flows, the $\mathrm{P}^{2}$ method). To apply these mathematically equivalent laws, a cross verification and validation has been realized on two different test rigs with different porous media (metallic and

\footnotetext{
${ }^{1}$ Associate Professor, corresponding author: Nicolas.Gascoin@bourges.univ-orleans.fr.
} 
composite) with a range of Darcian permeability varying from $10^{-17} \mathrm{~m}^{2}$ to $10^{-11} \mathrm{~m}^{2}$. The PRISME test bench has a lower accuracy for thick samples (over $3 \mathrm{~mm}$ ) due to lateral permeation while the DLR rig is free from such a phenomenon thanks to an innovative sealing (which is however not adapted to samples thinner than $3 \mathrm{~mm}$ ). The two test rigs are found to be complementary. The results are judged to be satisfactory (discrepancy around $14 \%$ for reference samples). The methods used to post-process the data can generate discrepancies up to a factor 2 . The method based explicitly on compressibility is chosen more specifically for its easiest application to Computational Fluid Dynamics. The ISO method accuracy is lower for small flow rate range.

Keywords: Ceramic Matrix Composites, Permeation, Active cooling, Darcy, Forchheimer.

\section{Nomenclature}

$C_{F} \quad=$ Forchheimer's coefficient ()

$K=$ Generic permeability term $\left(\mathrm{m}^{2}\right)$

$K_{D}=$ Darcian permeability $\left(\mathrm{m}^{2}\right)$

$K_{F} \quad=$ Forchheimer's permeability (m)

$L \quad=$ Porous media thickness $(\mathrm{m})$

$\dot{m}=$ Mass flow rate $\left(\mathrm{kg} . \mathrm{s}^{-1}\right)$

$n \quad=$ Exponentiel factor ()

$P \quad=$ Pressure $(\mathrm{Pa})$

$r \quad=$ Constant of real gas $\left(\mathrm{J} \cdot \mathrm{kg}^{-1} \cdot \mathrm{K}^{-1}\right)$

$S=$ Permeation surface (cross-section of fluid flow) $\left(\mathrm{m}^{2}\right)$

$T \quad=$ Temperature $(\mathrm{K})$

$V \quad=$ Fluid velocity $\left(\mathrm{m} . \mathrm{s}^{-1}\right)$ 
$x=$ Axial Cartesian coordinate in the direction of flow through the porous media, perpendicular to surface (m)

\section{Greek Symbols}

$$
\begin{aligned}
& \beta=\text { Permeation coefficient }\left(\mathrm{s}^{-1}\right) \\
& \mu \quad=\text { Dynamic Viscosity (Pa.s) } \\
& \rho \quad=\text { Density }\left(\mathrm{kg} \cdot \mathrm{m}^{-3}\right)
\end{aligned}
$$

\section{Subscripts}

in $\quad=$ inlet conditions

mean $=$ mean value between inlet and outlet conditions

out $=$ outlet conditions

\section{Introduction}

Due to high temperature levels encountered by structures notably during hypersonic flight, the thermal management increases the need of using carbon or oxidic based composite materials. Such materials offer low expansion, specific weight and higher strength at elevated temperatures compared to metallic materials. Several fabrication methods exist depending on the properties which are required for the composite material (impregnation of resin polymeric or silicon carbide- in a carbon fibrous form (Bouchez and Beyer, 2009; Peddiraju et al., 2005) or liquid silicon infiltration technique (Heidenreich, 2003)). The permeability of the material depends directly on the manufacturing process. Details on the oxidic materials used in the present paper can be found in the work of Heidenreich et al. (2004). For the latter, the Ceramic Matrix Composite (CMC) denomination is employed to refer to these media. The section A is dedicated to the presentation of the fluid flow in porous media, the section $\mathrm{B}$ to its analytical description and the section $\mathrm{C}$ to the equations selected for this work. 


\section{A. Permeation and related phenomena}

To apply these materials with respect to thermal management systems, it is of prior importance to study the transpiration of potential coolants through porous structures. This depends largely on several parameters ; among them : the porosity and permeability of the solid, the properties of the fluid, its pressure and its temperature. When using CMC structures for nozzle applications, the combination of high pressure and high temperature levels can gradually lead to a thermal destruction. It is further favoured by the extreme conditions and by the permeation of the resulting pyrolysis gases through the damaged CMC structure (Park and Lawrence, 2003). For other applications, the composite porous media can be transpiration cooled by means of inert or reactive fluids (Zhou et al., 2006). This technology is of potential interest for hypersonic flight conditions (Langener et al., 2008). In this configuration, the permeation of the fluid through the structure ensures internal convective cooling. The resulting film in the combustion chamber controls the heat exchange between the solid and the fluid. In porous media, the cooling efficiencies are much higher than in nonporous media, notably due to the increased internal exposure to the material (Krishna et al., 2008). Investigating the permeation process is of prior importance and some works can be found in relationship with this need : experimentally (Langener et al., 2008; Tully et al., 2005), numerically (Riccius et al., 2005; Murthy and Singh, 2000) and mathematically (Kim and Park, 1999). These studies are not limited to the flow behaviour. They also assess the heat transfers (Krishna et al., 2008; Murthy and Singh, 2000; Rajagopal et al., 2009, Zhang and Zhao, 1999; Hadim, 1994); for example for configurations close to fuel cooled structures (Zhao and Chen, 2003) or for geophysics applications (Hadim, 1994). This explains why the flows in porous media are so widely studied.

The permeability is a key data for the initial fibrous preform during the manufacturing process itself and not only for the finalised product. Indeed, the CMC structures are obtained 
by infiltration of resin inside the form (Ngo and Tamma, 2003). The permeability of the preform controls the impregnation of the resin and thus the final properties of the CMC structure. Due to low injection speed at high pressure, the flow of resin remains laminar and the Darcy's law can be used to describe such fabrication methodology (Raper et al., 1999). There is a high necessity to estimate the permeability of such fibrous form and numerous works are available to predict it experimentally (Park and Lawrence, 2003; Chung et al., 1997) numerically (Tully et al., 2005, Ngo and Tamma, 2003, Costa et al., 2004) or analytically (Gebart, 1992). The investigation on the permeability of the fibrous form is not the prime focus of the present study but the developed bench and methodology could serve for this purpose.

The permeation mainly depends on the materials structure which is determined by features on different scales (Zhou et al., 2006). It is affected by the material employed (composite, metal, ceramic...), the structure morphology (tubular, plate...), the layer number (simple or multilayer composite), the layer disposition (angle between each layer, i.e. $0^{\circ}$, $45^{\circ}$ or $90^{\circ}$ ), the presence of cracks (their orientation, the connexion between them) (Zhou et al., 2006; Soller et al., 2009; Federico and Herzog, 2008; Xu and Sankar, 2008; Shields et al., 2008; Kuhn and Hald, 2008; Choi et al., 1998) ${ }^{0}$, the aging and the damage (outer and inner cracking, delamination) (Park and Lawrence, 2003). At this scale, the manufacturing process has a huge effect on the material permeability. A lot of techniques are employed to produce very large composite panels : polymer impregnation and pyrolysis, melt infiltration, liquid phase sintering or hot pressing. As a consequence, the permeability can differ with several orders of magnitude (Hirohata et al., 2002). The cracks formation is probably the most important source of permeability modification. The SEM (Park and Lawrence, 2003), the Xrays (Peddiraju et al., 2005) and the tomography (Petrasch et al., 2008) techniques are used to monitor the cracks. When the fissures appear during tests at given temperature and pressure, 
the permeability changes suddenly and then remains constant if no further modifications of the test conditions are done (Park and Lawrence, 2003). The mechanical strain has also an impact on the crack formation (Peddiraju et al., 2005). This kind of damage is largely studied and numerous works propose empirical and analytical laws for permeability prediction in case of fissures presence (Peddiraju et al., 2005).

A lot of studies, often under high pressure (up to $2 \mathrm{MPa}$ ) are available for ambient or average temperature conditions (under $800 \mathrm{~K}$ ) (Peddiraju et al., 2005, Park and Lawrence, 2003; Langener et al., 2008; Tully et al., 2005) or for low pressure and high temperatures (Kuhn and Hald, 2008). Few are dedicated to both high temperature and high pressure conditions. Furthermore, they focus on the transpiration of "inert" gases (even oxidative ones like the air or non reactive ones like hydrogen) (Peddiraju et al., 2005; Park and Lawrence, 2003; Tully et al., 2005; Ortelt et al., 2009) and very few are studying the chemical reactions through the porous media (Gascoin et al., 2008). This configuration is yet encountered in the framework of this study related to the cooling of hypersonic structures.

The reactions of pyrolysis are due to the decomposition of heavy molecules into smaller ones due to the temperature. The residence time of the fluid through the porous media has a major impact on the chemical process, along with the pressure (Gascoin et al., 2008). As a consequence, it would be valuable to get permeation data to be able estimating numerically the residence time in porous media to analyse the chemical decomposition. This should be preferably achieved by numerical work and the permeability terms must be determined for this purpose.

\section{B. Analytical descriptions of through-flow}

For a large range of flow regimes, the Brinkman's equation is used to describe the macroscopic fluid flow (Eq. 1). The pressure drop through the porous media (left term) is linearly proportional to the velocity for low flow rates (Darcian flows) and to its square at 
higher flow rates (non-Darcian flows). The right term of the Eq. 1is composed of two parts, one related to the Darcy's law for low velocity regime filtration (second right term) and the other quadratic one related to the Stokes's law to ensure the continuity of velocity and stress at the solid-fluid frontier (first right term) (Park and Lawrence, 2003). The gravity term is neglected in numerous studies (but not all, for example in case of vertical flows (Zhao and Chen, 2003)). The Stokes equation, also referred to as the Forchheimer's equation, accounts for inertial effects related to the flow resistance (turbulent flows) (Tully et al., 2005; Riccius et al., 2005).

Theoretically, the 3-D field of the velocity should appear (Choi et al., 1998) when writing the through-flow equation. Instead, it is averaged macroscopically in the equations presented here. The Eq. 2 is equivalent to Eq. 1 but the dimensionless "Forchheimer's coefficient" $C_{F}$ appears and the second derivative of the velocity is easier to express, at least from an experimental point of view (Choi et al., 1998). The unity of Forchheimer's term is found in $\mathrm{m}$ or in $\mathrm{m}^{-1}$ in open literature depending on the writing of the equation used by the authors.

$$
\begin{gathered}
\frac{\partial P}{\partial x}=\mu \cdot\left(-\frac{\partial^{2} V}{\partial x^{2}}-\frac{V}{\mathrm{~K}}\right) \\
\frac{\partial P}{\partial x}=-\mu \cdot\left(\frac{C_{F \cdot} \rho \cdot V^{2}}{\sqrt{K}}+\frac{V}{\mathrm{~K}}\right)
\end{gathered}
$$

In Eq. 2, it is obvious that for high flow velocity, the square of the velocity makes the Forchheimer's term to be higher than the Darcy's one while for flow speed lower than $1 \mathrm{~m} . \mathrm{s}^{-}$ ${ }^{1}$, the Forchheimer's term get negligible. The so called Darcy-Forchheimer equations (Eq. 3) (Langener et al., 2008) is equivalent to the Eq. 2 but the permeability $K_{D}$ and $K_{F}$ explicitly appear. We have now independent and well identified Darcy’s and Forchheimer's terms. No negative sign appears contrary to previous equations.

$$
\frac{\Delta P}{L}=\mu \cdot \frac{V}{\mathrm{~K}_{D}}+\rho \cdot \frac{V^{2}}{\mathrm{~K}_{F}}
$$


Numerous other formulations of the Brinkman's equation are found (Martin and Boyd, 2008; Valdes-Parada et al., 2007) such as the Eq. 4 (Martin and Boyd, 2008) (no square velocity appears). They are based on coefficient that still need to be expressed and which physical meaning is not evident. Furthermore, the square of the velocity strangely disappears in the turbulent term (Eq. 4). Power laws (Rathish Kumar, 2003) and cubic laws (if $n=3$ in Eq. 5) can be found to describe a large range of flow regimes through porous media (Martin and Boyd, 2008; Valdes-Parada et al., 2007; Rathish Kumar, 2004; Aulisa et al., 2009; Nguyen et al., 2007; Pazos et al., 2009). The power law can be found under the name of Izbash law (Moutsopoulos, 2009). The fundamentals of the Brinkman's equation can be found in the work of Valdes-Parada et al. (2007) for more details.

$$
\begin{gathered}
\frac{\partial P}{\partial x}=-\mu \frac{V}{\mathrm{~K}}-\beta \cdot \rho \cdot V \\
-\frac{\partial P}{\partial x}=\mu \frac{V}{\mathrm{~K}}+\beta \cdot \rho \cdot V^{n}
\end{gathered}
$$

The filtration section of the porous sample is often used in the Stokes' equation because the flow rate is generally measured in experiments rather than the flow velocity. Nevertheless, the section occupied by the gas in a cross section of the gas-filled sample in the direction of the flow should be considered (Park and Lawrence, 2003). Furthermore, the dynamic viscosity, which appears in the Brinkman's equation, is often considered to be the one of the fluid. It remains constant in most of experimental and numerical works (as seen in Eq; 1 for example). Nevertheless, this is questionable because this parameter varies across the porous media in case of reactive flow or non uniform temperature system. The viscosity term in the Stokes' equation (first right term in Eq. 1) should be modified as follows: $\nabla(\mu \nabla V)$ (Martin and Boyd, 2008). Mathematical considerations can be found on this point to justify using a modified viscosity (Hansbo and Juntunen, 2009). A more rigorous derivation 
included temperature-dependent fluid properties in the estimation of pressure drops in combination with temperature gradients (Langener et al., 2008).

\section{Selection of methods for experimental data treatment}

Two methods are selected to determine the permeability of porous samples. The first one is related to the norm ISO 4022 (1987 with update in 2006). The Darcy-Forchheimer equation (Eq. 3) is rewritten (Eq. 6) by dividing it by $\mu . V$. The term $\frac{\Delta P}{L . \mu . V}$ is plotted as a function of $\frac{\rho . V}{\mu}$. The origin is linked to the Darcian term while the angle of climb is related to the Forchheimer's term.

$$
\frac{\Delta P}{L . \mu . V}=\frac{1}{K_{D}}+\frac{\rho . V}{\mu . K_{F}}
$$

The pressure gradient $\frac{\Delta P}{L}$ is calculated as follows (Eq. 7), based on experimental measures.

$$
\frac{\Delta P}{L}=\frac{P_{\text {in }}-P_{\text {out }}}{L}
$$

With this method, the dynamic viscosity, the density and the fluid velocity (Eq. 8 and 9) refer to mean values computed between the inlet and the outlet. Its applicability is more difficult for engineering tools or advanced Computational Fluid Dynamics codes than for experiments. The CFD software preferably rely on well defined upstream conditions (boundary conditions). Therefore, ESA and DLR are using a second method (Langener et al., 2008 (Hansbo and Juntunen, 2009) which is based on the integration of Eq. 3 assuming perfect gas and isothermal conditions. The integrated pressure loss is expressed by Eq. 10 (Seemann, 2005). When rearranging Eq. 6, by introducing the mean density (Eq. 8), mean velocity (Eq. 9), the continuity equation and the perfect gas law (Eq. 11), Eq. 12 is obtained 
and this gives the Eq. 13 used by ESA and DLR. This is the demonstration that both formulations (Eq. 6 and Eq.13) are mathematically equivalent. The right hand side of Eq. 13 is only dependent on inlet conditions. Consequently, this second method needs only to plot the pressure loss term (Eq. 13) as a function of measured inlet conditions to get both permeability terms by second order polynomial regression. To clarify the paper, the first method is called the "ISO method" and the second one the "P2 method".

$$
\begin{gathered}
\rho_{\text {mean }}=\frac{P_{\text {mean }}}{r \cdot T}=\frac{P_{\text {in }}+P_{\text {out }}}{2 \cdot r \cdot T} \\
V_{\text {mean }}=\frac{\dot{m}}{\rho_{\text {mean }} \cdot S} \\
\frac{\Delta P}{L}=\frac{P_{\text {in }}^{2}-P_{\text {out }}^{2}}{2 \cdot L \cdot P_{\text {in }}} \\
\frac{P_{\text {in }}^{2}-P_{\text {out }}^{2}}{2 \cdot S \cdot V}=\frac{P}{r \cdot T} \cdot S \cdot V \\
\frac{1}{K_{\text {in }} \cdot L \cdot \mu \cdot V_{\text {in }}}+\frac{\rho_{\text {in }}}{\mu \cdot K_{F}} \cdot V_{\text {in }} \\
\frac{\Delta P}{L}=\frac{P_{\text {in }}^{2}-P_{\text {out }}^{2}}{2 \cdot P_{\text {in }} \cdot L}=\frac{\mu}{K_{D}} V_{\text {in }}+\frac{\rho_{\text {in }}}{K_{F}} V_{\text {in }}^{2}
\end{gathered}
$$

With $V_{i n}=\frac{\dot{m}}{\rho_{i n} S}$

As an example, both methods are represented on Figure 1 for a set of experimental data (to be given in more details in section II). The curves are typical and very different because the ISO method (Figure 1a) gives a linear trend while a quadratic one is observed for $\mathrm{P}^{2}$ method (Figure $1 \mathrm{~b}$ ) in case of turbulent flow (above $0.4 \mathrm{~m} . \mathrm{s}^{-1}$ ). In case of a purely laminar flow (Darcian regime), the ISO method gives an horizontal line and the $\mathrm{P}^{2}$ method gives a linear trend and the Forchheimer's term cannot be determined for both cases. The present study aims at investigating the difference, if any, between these two methods when applied to same permeation data despite the fact that both equations are analytically equivalent as shown 
above. This work is related to the use of polynomial regression which may present some difficulties. We will investigate in which extend and we will determine whether one method or the other is preferable depending on the available range of permeation data. Furthermore, these permeation results have been acquired with two test benches, localized in France and in Germany. These two rigs are presented in section II with the selected porous media before being compared in section III to estimate their respective ability.

Figure 1 should be placed here

\section{Description of permeation benches}

The permeation bench of DLR has been developed since 2000 and the one of PRISME since 2009. Both are derived from previous installations concerning subsonic rocket chamber combustion (Ortelt, 2009)/reentry applications (Kuhn and Hald, 2008) and fuel pyrolysis (Gascoin et al., 2010; Gascoin, 2010) respectively. The DLR bench is able to handle gas flows (e.g. Air, Ar, He, $\mathrm{N}_{2}$ ) at inlet pressures up to $3 \mathrm{MPa}$ under perfectly controlled conditions. By means of a peripheral elastomer sealing mechanism of the sample (under patent), leak-proof test conditions are guaranteed. The PRISME bench is made to test permeation of inert and reactive gases and liquids (single or multi-components) under high temperature and pressure conditions (1200 K, $6 \mathrm{MPa})$. Two "chambers" have been designed specifically to allow pyrolysis products sampling in good conditions (under patent).

\section{A. PRISME test bench}

A high pressure and high temperature test bench has been set up to enable the study of inert and reactive flows through porous structures. More details can be found in the work of Seemann (2005). The experiment (derived from the one of the COMPARER project (Gascoin, 2010)) is composed of a high pressure pump (8 MPa, 0.5 g.s ${ }^{-1}$ ) for liquid fuel injection and of a gas injection with e.g. $\mathrm{N}_{2}, \mathrm{CH}_{4}$. The fluid is heated by a $6 \mathrm{~kW}$ oven 
(maximum temperature of $1900 \mathrm{~K}$ ). The reactor is composed of a permeation cell in which the porous medium is inserted (to be described later in Figure 2). Over 30 sensors (temperature, pressure, mass flow rate) are connected to a data acquisition system (about $1 \mathrm{~Hz}, 16$ bits) to obtain the transient variations of these parameters. The pressure transducers give absolute pressure and two Coriolis mass flow meters are available (upstream and downstream). Three other flow meters are available to measure the mass transfer in the bench to check the mass balance during the test. At least two temperatures are acquired inside the test cell on each faces of the porous sample. The tests are generally conducted under steadystate conditions but transient phases can be investigated.

The specific cell to be inserted in the furnace is composed of two main parts (High Pressure Chamber -HPC- for the inlet side and Low Pressure Chamber -LPC- for the outlet one) in order to maintain the porous medium in the fluid flow and to avoid leakage (Figure 2). Despite its small size (external diameter of $40 \mathrm{~mm}$ ), it enables measuring the temperature, pressure and mass flow rate on each side of the porous sample. The temperature is measured very close to the media to get the thermal longitudinal gradient, if any. Due to the available range of sensors, a maximum value of measurable Darcian permeability can be estimated as a function of test conditions (Table 1). The thickness of the sample impacts directly on this limit.

Usually, the mass flow of test liquid is increased by successive plateaus under fixed conditions of oven temperature and of downstream fluid pressure. By doing so, mass flow can be correlated to pressure losses which increase with the flow rate rise. ISO method or $\mathrm{P}^{2}$ method can be used to post-process the data even if the ISO method is preferred for liquid since the flow rate are generally low (as will be exposed in section III-A). If gas is preferred for the test, an isothermal plateau is chosen and the upstream pressure is increased gradually. This imposes the mass flow through the permeable sample and the downstream pressure is 
measured. Using the relationship between flow rate and pressure drop (Eq. 6 or Eq. 13) gives the permeability terms. This test procedure is reproduced for several thermal plateaus.

Figure 2 should be placed here

Table 1 should be placed here

\section{B. DLR test bench}

A moderate pressure test facility has been set up to enable the study of inert flow through porous structures at room temperature (Figure 3 ). The gas (typically, $\mathrm{N}_{2}$ ) flows through a permeable sample which is embedded in a sample holder. Nitrogen is allocated in a tank and it is being reduced by a control valve, which allows choosing the desired mass flow rates. A coriolis flow meter with an accuracy of $0.1 \%$ is used. The test gas will be fed into the sample holder, where the permeable sample is tightly fixed without a change in the holder section. Here, a circumferentially sealing mechanism avoids falsifying leakage flows. Before the sample, the test gas temperature $T_{i n}$ and pressure $P_{\text {in }}$ will be measured by a type $\mathrm{K}$ thermocouple (accuracy $2.2 \mathrm{~K}$ ) and an OMEGA ${ }^{\mathrm{TM}}$ pressure sensor (accuracy of $0.05 \%$, depending on the full scale of $3 \mathrm{MPa}$ adjusted), respectively. By flowing through the sample nitrogen passes off against ambience, where the ambient pressure $P_{\text {out }}$ will be recorded by an $\mathrm{OMEGA}^{\mathrm{TM}}$ pressure sensor (accuracy $0.05 \%$ for full scale of $0.5 \mathrm{MPa}$ ).

\section{Figure 3 should be placed here}

The samples to be measured are circular with a diameter of $30 \mathrm{~mm}$. They have to be flat, whereupon the thickness can vary between $3 \mathrm{~mm}$ and $40 \mathrm{~mm}$. The test procedure usually consists of the following static measurement method. During a test, different test gas mass flows are adjusted in order to receive varying pressure losses over the permeable sample. In doing so, a set of points for the measured data is gained, which are the basis for later postanalysis. Those measured data points are used to determine the permeabilities $K_{D}$ and $K_{F}$ by 
means of a least squares fit of the multivariate function (see Eq. 13). For the analysis, the test gases are usually being treated and calculated as real gases.

\section{Characterization of porous media to be studied}

Several samples of different nature (metallic and composite) have been tested to provide a large validation of the test benches and of the determination methods. Most of them have been previously used in former studies (Gascoin et al., 2010; Ortelt et al., 2009; Soller et al., 2009). A selection is used on both test rigs to furnish comparison data. One red brass sample (BR30) (Gascoin et al., 2010) and two stainless steel samples (SS3 and SS3-2) (Gascoin et al., 2010) furnished by Federal Mogul (Poral Class), a set of two kinds of C/SiC samples (SB and SC) furnished by MBDA (SB1, SC2/4/5/6/8) (Gascoin et al., 2010) and a set of various composite samples furnished by DLR (OXIPOL (Heidenreich et al., 2004) and C/C random (Heidenreich, 2003) with flow penetration in-plane and perpendicular to the plies each) (Soller et al., 2009) have been used (Figure 4). The thickness of DLR samples is $30 \mathrm{~mm}$. Further data for these samples are given in Table 2 and Table 3. The OXIPOL samples (Oxide based CMC based on polymers, 3-times pyrolysed (Nitivy 2626P mullite fibers in SiOC matrix)) are called I678L-05 and 06 (respectively cut perpendicularly to the fiber layers or parallel). The $\mathrm{C} / \mathrm{C}$ random samples (Carbon fiber reinforced carbon $\mathrm{CMC}$ with $\mathrm{C}$ fibers in C matrix) are called PH1431-05 and 06 (respectively cut perpendicularly to the fiber layers or parallel).

Figure 4 should be placed here

Table 2 should be placed here

Table 3 should be placed here 


\section{Results and Discussion}

All the data acquired by PRISME on porous samples have been post-processed by both ISO and $\mathrm{P}^{2}$ methods. The quadratic regressions are forced by origin and several software have been used for the $\mathrm{P}^{2}$ application : some commercial and free ones and a DLR in-house program. The metallic and MBDA porous media were successively tested by PRISME and DLR. On the opposite, the DLR samples were consecutively tested by DLR and PRISME. This is mentioned because the permeable materials can get jammed up by impurities, oil and particles during the tests. The objectives are to determine the validity of the measures and the difference of both analytical methods, if any.

\section{A. Application of both permeability determination methods on PRISME data}

All the tests conducted with the PRISME test bench under ambient temperature with $\mathrm{N}_{2}$ flow on porous media have been post-processed with both the ISO and $\mathrm{P}^{2}$ method to obtain the two permeability coefficients (Table 4). It must be noted that Excel software is used for both methods (this has an importance for the following). The discrepancies are represented by the ratio of permeability values found with each method. This ratio is plotted as a function of permeability obtained with ISO method (Figure 5 for Darcy's term). Most of the values are found to be between 0.5 and 2 . This is judged to be very large because the method should not impact on the value which is determined. This highlights the importance of this work since this problem could have been unsuspected before. The values closest to equality are found in majority for Darcy's permeability from $3.10^{-16} \mathrm{~m}^{2}$ to $2.10^{-14} \mathrm{~m}^{2}$. For higher Darcian values, the $\mathrm{P}^{2}$ method gives higher permeability than the ISO ones. Consequently, their must be a reason for these discrepancies.

Table 4 should be placed here

Figure 5 should be placed here 
For low permeability $\left(10^{-15} \mathrm{~m}^{2}\right.$ and under), the inlet pressure is highly increased to get a minimum flow rate. Due to the limitation of upstream pressure, it is difficult to get enough data points to reach the linear trend observed previously (Figure 1). As a consequence, the ISO method seems to be less adapted than $\mathrm{P}^{2}$ one for low mass flow rates. The exploitation is made to close to the origin and in this condition, the $\mathrm{P}^{2}$ method or a pure Darcy's law (pressure loss as a function of velocity) is better. On the opposite, the turbulent regime is easily reached for high permeability $\left(10^{-13} \mathrm{~m}^{2}\right.$ and above). Since a linear regression is easier to apply than a quadratic one, the ISO method has an advantage on $\mathrm{P}^{2}$ one.

Furthermore, the ratio of Darcian permeabilities determined by both methods seems to be dependent on the tested samples (Figure 6). No particular trend is observed for metallic samples whereas both methods show a better agreement for MBDA and DLR samples with increase of porosity. The ratio of the Forchheimer's permeability term is rarely close to 1 but merely comprised between 2 and 3 (Figure 7). This needs to be investigated in more details and the explanation is given at the end of the next paragraph.

\section{Figure 6 should be placed here}

\section{Figure 7 should be placed here}

These discrepancies could finally be pinned down to the applied $2^{\text {nd }}$ order polynomial regression software of Excel when applying the $\mathrm{P}^{2}$ method. As an example, the outcome of the data post-processing by Excel for high mass flow rate is demonstrated in Figure 8a. The Darcy's term is found to be negative despite the determination factor is acceptable (0.9899). This may be related to the oscillation of mass flow rate which correspond to no quasi-static conditions. Some cases for which the application of $\mathrm{P}^{2}$ method was difficult (because of this software limitation) have been post-processed a posteriori with a DLR in-house program based on a better Classical Least Square regression algorithm. The experimental data are fitted by this code (cross on Figure 8b) and the Excel software is still not able to provide 
realistic permeation data (Figure 8b). This is due to the non constant coefficients, which are not considered by Excel. Several other software have been tested with same unsatisfactory results (NCSS, NLREG, Origin, Gnuplot). As a consequence, the values between both ISO and $\mathrm{P}^{2}$ methods (obtained with the DLR code) are much closer than with previous regression application of the $\mathrm{P}^{2}$ method (Table 5). A value very close to unity is found for most of the cases and particularly for the Forchheimer's term for which a bad agreement was found previously. To conclude, despite the exact analytically equivalence of both methods, the data post-processing methodology has a dramatic impact on the permeation values. If both methods are theoretically suitable, the ISO one is simple (linear regression) but the $\mathrm{P}^{2}$ method is absolutely equivalent and it is to be preferred for engineering analysis or simulation purpose $^{40}$. These results are important because they should be considered in the recommendation of the international norm ISO4022.

\section{Figure 8 should be placed here}

\section{Table 5 should be placed here}

\section{B. Cross-bench of permeation data obtained with PRISME and DLR test rigs}

The samples presented in section II-C are studied with both PRISME and DLR test benches. The PRISME data are post-processed with ISO method and the DLR ones by $\mathrm{P}^{2}$ method (Table 6). For the MBDA samples, DLR used an adapter (Figure 9). For each of those samples, two values are given because there is no clear determination concerning the cross-section to be considered which is greater at the inlet than at the outlet of the sample (diameters $16 \mathrm{~mm}$ and $30 \mathrm{~mm}$ on Figure 9). These two values surely represent the bounds of the real permeation value for the related sample. Two values for SC4 and SC8 samples are also given for the PRISME bench because two kinds of tests were done. The first was a sudden rise and the second a progressive increase of the upstream gas pressure. The purpose 
was to detect whether there is any influence by the dynamics of the pressure increase during the test. The low disagreement between values shows that this point is negligible.

Two SS3 samples ("new" -never tested- and "old" -which underwent several tests-) were considered. This virgin sample and the other one with incrusted carbon seal (applied on the surface for the PRISME test bench), were tested at the DLR bench. The one with carbon seal is obviously less permeable $-60 \%$ of decrease- (Table 6).

\section{Table 6 should be placed here}

\section{Figure 9 should be placed here}

On the basis of all the other values, the agreement between the two benches is generally in the right order of magnitude. Nevertheless, the discrepancies can reach a factor ten for some tests. The PRISME test facility provides generally better values for more dense materials than the DLR one. This is attributed to a better accuracy for small mass flows. Small thicknesses are also difficult to be managed by the DLR bench.

The PRISME data have also been compared to former values from the ATLLAS program (Bouchez et al., 2009) (Table 7). Two values are proposed for Oxypol I678L-05, PH1431-05 and PH1431-06 in ATLLAS data because two similar samples were tested. Two values for PH1431-05 are also given for PRISME data because of a sealing test (which will be explained later in this paragraph). The ratio between the PRISME and ATLLAS values is largely different from unity and again, one order of magnitude can be found. This disagreement has been analyzed and it is now understood. The PRISME bench is not adapted to thick samples. Indeed, due to the sealing process ensured by a circular carbon seal applied on the extremity of the sample (and not by a circumferential seal as used by DLR), strong leakage is possible in the lateral direction (perpendicular to the main flow). Some of the considered samples (30 mm thick) are more porous in the transverse direction (anisotropic properties). As a consequence, the fluid flows directly out of the sample and downstream 
before flowing transversally again inside the sample (as illustrated on Figure 10, right). This has been confirmed by sealing the border of the sample by glue (Figure 10, left). The value of glued sample is given in Table 7. Of course, this coarse methodology is made for qualitative purpose only and cannot be considered to avoid this problem because the permeation of the glue itself and of the deposition process is not characterized. The newly estimated Darcy's term is $2.45 .10^{-13} \mathrm{~m}^{2}$ and the Forchheimer's one is $3.48 .10^{-8} \mathrm{~m}$. These values correspond to a ratio which is divided by more than 2 for Darcy's term and somewhat less than 2 for Forchheimer's term. Consequently, ensuring a better tightness seal of the sample borders give permeability values closer to the ATLLAS ones. This indicates the main limit of the PRISME bench which should not be used for sample thicknesses over $3 \mathrm{~mm}$.

Table 7 should be placed here

Figure 10 should be placed here

\section{Conclusion}

It is of prior importance to get reliable data on space structures, particularly for actively cooled composites. The reliability of permeabilities (Darcy's and Forchheimer's terms) is linked to the acquisition of data in the one hand and to their post-processing on the other hand. Due to the large discrepancies (several factors) which are generally found in open literature work, two test bench have been settled under an European collaborative work between ESA (The Netherlands), MBDA and the University of Orléans (France) and DLR (Germany). A good complementarity is found for both test rigs. The PRISME bench is not adapted to thick samples (higher than $3 \mathrm{~mm}$ ) because of uncontrolled lateral permeation for heterogeneous samples, such as composite ones. On the opposite, the DLR test facility is not able to handle thin samples (lower than $3 \mathrm{~mm}$ ) because the sealing is ensured circumferentially with e.g. an elastomeric seal. Furthermore, due to the limitation of pressure sensors, the PRISME bench is mostly suitable for Darcian permeability from $10^{-17} \mathrm{~m}^{2}$ to $10^{-13}$ 
$\mathrm{m}^{2}$ (high pressure drop and low mass flow rate such as in regenerative cooling structures). Complementarily, the DLR experiment is suited for values of $10^{-14} \mathrm{~m}^{2}$ and higher (low pressure drop and high mass flow rate such as encountered in active cooling technology) due to limited fluid supply system. For a common range of Darcy's permeability around $10^{-14} \mathrm{~m}^{2}$ to $10^{-13} \mathrm{~m}^{2}$, a good agreement (14\%) is found between the results obtained with both test rigs. This result is very important because the disagreement which is generally observed on permeabilities in open literature can reach several factors of magnitude. Establishing two complementary test facilities is of importance to verify the accuracy of the permeabilities which are determined on aerospace structures.

To ensure the adaptation of permeability values to engineering tools or CFD codes, the $\mathrm{P}^{2}$ method has been chosen because it is based on the inlet conditions and not the mean one in the porous media as it is the case for the ISO method. The regression of experimental data points by a second order polynomial curve with commercial software remains of poor quality in case of oscillating permeation data. In such cases, a dedicated program is required to successfully and accurately determine both permeation terms. The ISO method -the standard of the international norm 4022- is very convenient from a post-processing point of view (linear regression). Nevertheless, its accuracy is not as good as the $\mathrm{P}^{2}$ method one when the range of flow rate is too small. This corresponds to cases with low permeability materials used for regenerative cooling activities. Consequently, future tests should be conducted with high pressure supply system (25 MPa) to reach high mass flow. The norm ISO 4022 only mentions that five hydraulic plateaus should be used. The range of hydraulic conditions is not detailed. This work shows that a supplementary criterion should be given. This is the second important point of this work. It is shown how the post-processing method can modify the values of permeability. 


\section{Acknowledgments}

This work was supported by the ESA-ESTEC, Contract no.: 3-12861/09/NL/PA. The authors would like to sincerely thank B Le Naour and J Bertrand from MBDA-France for their help involving this project. The highly valuable work of D. Blanc and D. Courilleau involving the measurement cell of PRISME bench has been greatly appreciated.

\section{References}

Aulisa E., Ibragimov A, Toda M, Geometric framework for modeling nonlinear flows in porous media, and its applications in engineering, Nonlinear Analysis: Real World Applications, Volume 11, Issue 3, June 2010, Pages 1734-1751.

Bouchez M, Dufour E, Cheuret F, Steelant J, Grenard P, Benezech L, Redford J, Sandham N, Roberts G, Passaro A, Baccarella D, Dalenbring M, Cavagna L, Multi-Level Coupled Simulations of Cooled Structures in the ATLLAS European Programme, $16^{\text {th }}$ Hypersonic congress, Breme Germany, October 2009, AIAA 2009-7355

Bouchez M, Beyer S, PTAH-SOCAR Fuel-Cooled Composite Materials Structure: 2009 Status, 16th AIAA/DLR/DGLR International Space Planes and Hypersonic Systems and Technologies Conference, October 2009, Bremen, Germany, AIAA 2009-7353

Choi M.A, Leeb M.H., Chang J., Jong Leed S., Permeability modeling of fibrous media in composite processing, J. Non-Newtonian Fluid Mech. 79, pp. 585-598, 1998.

Chung P.W., Ngo N.D, Tamma K.K., Permeability Approximations and Process Modeling of Geometrically Complex Composite Structures Manufactured by Resin Transfer Molding, AIAA 1997-140

Costa V.A.F., Oliveira M.S.A., Sousa A.C.M., Numerical simulation of non-Darcian flows through spaces partially filled with a porous medium, Computers and Structures 82 (2004) 1535-1541 
Federico S., Herzog W., On the permeability of fibre-reinforced porous materials, International Journal of Solids and Structures 45, pp. 2160-2172, 2008.

Gascoin N, Gillard P, Bernard S, Daniau E, Bouchez M, Pyrolysis of Supercritical Endothermic Fuel: Evaluation for Active Cooling Instrumentation., International Journal of Chemical Reactor Engineering, Vol. 6, Article A7, Ed. The Berkeley Electronic Press, 2008

Gascoin N, Fau G, Bioud J, Gillard P, Permeation of inert and supercritical reactive fluids through metallic and composite media, $46^{\text {th }}$ JPC AIAA, Nashville, July 2010, AIAA-20106551

Gascoin N, Etude et mesure de paramètres pertinents dans un écoulement réactif application au refroidissement par endo-carburant d'un super-statoréacteur, Editions Universitaires Européennes, avril 2010, ISBN13: 978-6131501074, 376 pages.

Gebart B.R., Permeability of unidirectional Reinforments for RTM, Journal of Composite Materials, 26(8) 1100-1133, 1992

Hadim A, Numerical Study of Non-Darcy Mixed Convection in a Vertical Porous Channel, J. Thermophysics and Heat Transfer, 1994, Vol. 8, No. 2: Technical Notes

Hansbo P. and Juntunen M., Weakly imposed Dirichlet boundary conditions for the Brinkman model of porous media flow, Applied Numerical Mathematics 59 (2009) 12741289

Heidenreich B., Herstellung von Faserkeramiken nach dem Flüssigsilicierverfahren (LSITechnik), in Keramische Verbundwerkstoffe, Weihnheim, Wiley-VCH, pp. 48-75, 2003.

Heidenreich B., Krenkel W., Frieß M., Gedon H., Net Shape Manufacturing of Fabric Reinforced Oxide/Oxide Components via Resin Transfer Moulding and Pyrolysis, 28th International Cocoa Beach Conference on Advanced Ceramics and Composites, Cocoa Beach, USA, 26-30 January 2004. 
Hirohata Y., Jinushi T., Yamauchi Y., Hashiba M., Hino T., Katoh Y., Kohyama A., Gas permeability of SiC_SiC composites as fusion reactor material, Fusion Engineering and Design 61-62, pp. 699-704, 2002.

Kim M.-Y. and Park E.-J., Fully Discrete Mixed Finite Element Approximations for NonDarcy Flows in Porous Media, Computers and Mathematics with Applications 38 (1999) 113-129

Krishna D.J., Basak T., Das S.K., Natural convection in a heat generating hydrodynamically and thermally anisotropic non-Darcy porous medium, International Journal of Heat and Mass Transfer 51 (2008) 4691-4703

Kuhn M. and Hald H., Application of Transpiration Cooling for Hot Structures, in: RESPACE - Key Technologies for Reusable Space Systems, Notes on Numerical Fluid Mechanics and Multidisciplinary Design 98, p. 82-103, Springer, Berlin, 2008.

Langener T., von Wolfersdorf J., Laux T., Steelant J., Experimental Investigation of Transpiration Cooling with Subsonic and Supersonic Flows at Moderate Temperature Levels, 44th AIAA/ASME/SAE/ASEE Joint Propulsion Conference \& Exhibit 21 - 23 July 2008, Hartford, CT, AIAA 2008-5174

Martin A and Boyd I.D., Simulation of pyrolysis gas within a thermal protection system, 40th Thermophysics Conference 23 - 26 June 2008, Seattle, Washington, AIAA 2008-3805

Moutsopoulos K.N., Exact and approximate analytical solutions for unsteady fully developed turbulent flow in porous media and fractures for time dependent boundary conditions, Journal of Hydrology 369 (2009) 78-89

Murthy P.V S.N. and Singh P., Thermal Dispersion Effects on Non-Darcy Convection over a Cone, Computers and Mathematics with Applications 40 (2000) 1433-1444 
Ngo N.D., Tamma K.K., Complex three-dimensional microstructural permeability prediction of porous fibrous media with and without compaction, $41^{\text {st }}$ Aerospace Sciences Meeting and Exhibit 6-9 January 2003, Reno, Nevada, AIAA 2003-1036

Nguyen Q.P., Currie P.K., Buijse M; Zitha P.L.J., Mapping of foam mobility in porous media, Journal of Petroleum Science and Engineering 58 (2007) 119-132

Ortelt M., Hald H., Herbertz A., Suslov D., Arnold R., Haidn O., Investigations of Transpiration Cooled Fibre Reinforced Combustion Chamber Structures in LOX/LH2 Operation, 45th AIAA/ASME/SAE/ASEE Joint Propulsion Conference \& Exhibit, Denver, CO, USA, 2-5 August 2009, AIAA 2009-5475.

Park O.Y., Lawrence TW., High Temperature Permeability of Carbon Cloth Phenolic Composite, 39th AIAA/ASME/SAE/ASEE Joint Propulsion Conference and Exhibit 20-23 July 2003, Huntsville, Alabama, AIAA 2003-5242

Pazos F.A., Bhaya A., Martins Compan A.L., Calculation of Klinkenberg permeability, slip factor and turbulence factor of core plugs via nonlinear regression, Journal of Petroleum Science and Engineering 67 (2009) 159-167

Peddiraju P., Grenoble R., Fried K., Gates T., Lagoudas D.C., Analytical Predictions and Experimental Measurements of Hydrogen Permeability in a Microcrack Damaged Composite, 46th AIAA/ASME/ASCE/AHS/ASC Structures, Structural Dynamics \& Materials Conference, 18-21 April 2005, Austin, Texas, AIAA 2005-2087

Petrasch J., Meier F., Friess H., Steinfeld A., Tomography based determination of permeability, Dupuit-Forchheimer coefficient, and interfacial heat transfer coefficient in reticulate porous ceramics, International Journal of Heat and Fluid Flow 29 (2008) 315-326

Rajagopal K.R., Saccomandi G., Vergori L., A systematic approximation for the equations governing convection-diffusion in a porous medium, Nonlinear Analysis: Real World Applications, Volume 11, Issue 4, August 2010, Pages 2366-2375. 
Raper K. S., Roux J. A., Vaughan J. G., Lackey E., Permeability Impact on the Pressure Rise in a Pultrusion Die, Journal Of Thermophysics And Heat Transfer Vol. 13, No. 1, January-March 1999

Rathish Kumar B.V., Free convection in a non-Darcian wavy porous enclosure, International Journal of Engineering Science 41 (2003) 1827-1848

Riccius J.R., Greuel D., Haidn O. J., Leicht T., Coupled CFD Analysis of the Hot Gas and the Coolant Flow in Effusion Cooled Combustion Chambers, 41st AIAA/ASME/SAE/ASEE Joint Propulsion Conference \& Exhibit 10-13 July 2005, Tucson, Arizona, AIAA 2005-4437.

Seemann B., Détection de fuite, Techniques de l'Ingénieur, R2055, March 2005.

Shields R.J., Bhattacharyya D., Fakirov S., Oxygen permeability analysis of microfibril reinforced composites from PE_PET blends, Composites: Part A 39, pp. 940-949, 2008.

Soller S., Kirchberger C., Kuhn M., Langener T., Bouchez M., Steelant J., Experimental Investigation of Cooling Techniques and Materials for Highspeed Flight Propulsion Systems, 16th AIAA/DLR/DGLR International Space Planes and Hypersonic Systems and Technologies Conference, October 2009, Bremen, Germany, AIAA 2009-7374

Tully L.R., Omar A., Chung J.N., Carroll B.F., Tucker P.K., Fluid Flow and Heat Transfer in a Liquid Rocket Fuel Injector, 41st AIAA/ASME/SAE/ASEE Joint Propulsion Conference \& Exhibit 10-13 July 2005, Tucson, Arizona, AIAA 2005-4127

Valdes-Parada F.J., Ochoa-Tapia J.A., Alvarez-Ramirez J., On the effective viscosity for the Darcy-Brinkman equation, Physica A 385 (2007) 69-79

$\mathrm{Xu}$ J. and Sankar B.V., Prediction of stitch crack evolution and gas permeability in multidirectional composite laminates, Composites: Part A 39, pp. 1625-1631, 2008.

Zhang B. and Zhao Y., Numerical Simulations o Fluid Flow ad Convection Heat Transfer Through Fluid/Porous Layers, AIAA 1999-3627 
Zhao J.Z. and Chen T.S., Non-Darcy Effects on Nonparallel Thermal Instability of Horizontal Natural Convection Flow, Journal Of Thermophysics And Heat Transfer Vol. 17, No. 2, April-June 2003

Zhou F., Kuentzer N., Simacek P., Advani S.G., Walsh S., Analytic characterization of the permeability of dual-scale fibrous porous media, Composites Science and Technology 66, pp. 2795-2803, 2006 
Table 1. Maximum measurable Darcian term on PRISME bench due to limitation of measurement devices as a function of operating conditions.

\begin{tabular}{|c|c|c|c|}
\hline & \multicolumn{3}{|c|}{ Fluid Phase } \\
\hline & GAS & LIQUID & $\begin{array}{c}\text { 20\% Pyrolysis } \\
\text { (Gascoin 2010) }\end{array}$ \\
\hline Mass flow rate $\left(\mathrm{g} \cdot \mathrm{s}^{-1}\right)$ & 1 & 0.2 & 0.2 \\
\hline Density $\left(\mathrm{kg} \cdot \mathrm{m}^{-3}\right)$ & 1.25 & 750 & 100 \\
\hline Dynamic viscosity (Pa.s) & 1.65E-05 & 1.30E-03 & $1.20 \mathrm{E}-05$ \\
\hline $\begin{array}{l}\text { Minimum measurable pressure loss } \\
\qquad(\mathrm{Pa})\end{array}$ & 2000 & 2000 & 2000 \\
\hline Cross-section $\left(\mathrm{m}^{2}\right)$ & 2.01E-04 & 2.01E-04 & 2.01E-04 \\
\hline Sample thickness (mm) & \multicolumn{3}{|c|}{$\begin{array}{l}\text { Maximum measurable darcian } \\
\text { permeability }\left(\mathrm{m}^{2}\right)\end{array}$} \\
\hline 3 & $9.85 \mathrm{E}-11$ & $2.59 \mathrm{E}-12$ & $1.79 \mathrm{E}-13$ \\
\hline 9 & $2.95 \mathrm{E}-10$ & $7.76 \mathrm{E}-12$ & 5.37E-13 \\
\hline 30 & $9.85 \mathrm{E}-10$ & $2.59 \mathrm{E}-11$ & 1.79E-12 \\
\hline
\end{tabular}


Table 2. Properties and pore diameter of porous media obtained experimentally ${ }^{0}$.

\begin{tabular}{|c|c|c|c|c|c|c|c|c|c|}
\hline & \multicolumn{4}{|c|}{ Stainless Steel } & \multicolumn{2}{|c|}{ Red Brass } & & \multicolumn{2}{|c|}{ Composite } \\
\hline \multirow[t]{2}{*}{ Density (kg.m-3) } & \multicolumn{4}{|c|}{7850} & \multicolumn{2}{|c|}{8800} & \multicolumn{3}{|c|}{1600} \\
\hline & \multicolumn{2}{|c|}{ Class 3} & Class 5 & Class 40 & Class 3 & Class 30 & & \multicolumn{2}{|c|}{$\mathrm{C} / \mathrm{SiC} \mathrm{CMC}$} \\
\hline Thickness (mm) & 2 & 3 & 3 & 3 & 3 & 3 & 1.5 & 4.5 & 7.5 \\
\hline Fabrication & \multicolumn{6}{|c|}{ spheres based material } & \multicolumn{2}{|c|}{ weaved layers } & $\begin{array}{c}3 \text { different } \\
\text { layers linked }\end{array}$ \\
\hline Overall porosity () & $28.3 \%$ & $30.4 \%$ & $34.3 \%$ & $39.7 \%$ & $40.3 \%$ & $44.0 \%$ & $8.8 \%$ & $13.3 \%$ & $30.9 \%$ \\
\hline Open porosity 0 & \multicolumn{2}{|c|}{$9.1 \%$} & $25.1 \%$ & $47.2 \%$ & $42.0 \%$ & $33.7 \%$ & $2.6 \%$ & $6.9 \%$ & $15.9 \%$ \\
\hline $\begin{array}{l}\text { SEM equivalent grain } \\
\text { diameter }(\mu \mathrm{m})\end{array}$ & 10.1 & 14.1 & 23.7 & 97.3 & 9.2 & 119.4 & 1.56 & 3.3 & 0.57 \\
\hline $\begin{array}{l}\text { Computed pore } \\
\text { diameter }(\mu \mathrm{m})\end{array}$ & 2.9 & 4.1 & 8.2 & 42.7 & 4.2 & 62.6 & 0.09 & 0.34 & 0.17 \\
\hline Porous sample $n^{\circ}$ & ss3-2 & $\mathrm{sS} 3$ & SS5 & $S S 40$ & BR3 & BR30 & sc & SB & SW \\
\hline
\end{tabular}


Table 3. Thermo-mechanical properties at room temperature for DLR CMC materials used in cooling investigation tests

\begin{tabular}{|l|c|c|c|c|c|}
\hline \multicolumn{1}{|c|}{ Material } & $\begin{array}{c}\rho \\
{\left[\mathbf{g} / \mathbf{c m}^{3}\right]}\end{array}$ & $\begin{array}{c}\mathbf{e}^{\prime} \\
{[\%]}\end{array}$ & $\begin{array}{c}\sigma_{\max } \\
{[\mathbf{M P a}]}\end{array}$ & $\begin{array}{c}\mathbf{C}_{\mathbf{p}} \\
{[\mathbf{J} / \mathbf{g} \cdot \mathbf{K}]}\end{array}$ & $\begin{array}{c}\lambda_{\|} \\
{[\mathbf{W} / \mathbf{m} \cdot \mathbf{K}]}\end{array}$ \\
\hline${\mathrm{C} / \mathrm{C}_{\text {random }}}$ & $1.35-1.39$ & $11-14$ & 109 & 0.88 & 8.20 \\
\hline OXIPOL $_{3 \times \text { pyrol. }}$ & $1.96-2.15$ & $11-16$ & 74 & 0.91 & 0.76 \\
\hline
\end{tabular}


Table 4. Darcian and Forchheimer's terms determined with same set of experimental

\section{data with two methods.}

\begin{tabular}{|c|c|c|c|c|c|c|c|}
\hline & \multirow[b]{2}{*}{$\begin{array}{c}\text { Open } \\
\text { porosity (\%) }\end{array}$} & \multicolumn{3}{|c|}{ Darcian permeability $\left(\mathrm{m}^{2}\right)$} & \multicolumn{3}{|c|}{ Forchheimer's permeability (m) } \\
\hline & & $\begin{array}{c}\text { ISO } \\
\text { Method }\end{array}$ & $\mathrm{P}^{2}$ Method & $\begin{array}{c}\mathrm{ISO} / \mathrm{P}^{2} \text { methods } \\
\text { ratio }()\end{array}$ & $\begin{array}{c}\text { ISO } \\
\text { Method }\end{array}$ & $\mathrm{P}^{2}$ Method & $\begin{array}{c}\mathrm{ISO} / \mathrm{P}^{2} \text { methods } \\
\text { ratio }()\end{array}$ \\
\hline SS3 & 9.1 & $2.27 \mathrm{E}-13$ & $2.36 \mathrm{E}-13$ & 0.96 & $5.63 \mathrm{E}-07$ & $2.48 \mathrm{E}-07$ & 2.27 \\
\hline SS3-2 & 9.1 & $1.16 \mathrm{E}-13$ & $5.52 \mathrm{E}-13$ & 0.21 & $1.59 \mathrm{E}-07$ & 1.75E-08 & 9.09 \\
\hline SS5 & 25.1 & $9.90 \mathrm{E}-13$ & 2.49E-11 & 0.04 & 9.19E-07 & 1.43E-07 & 6.43 \\
\hline SS40 & 47.2 & $1.54 \mathrm{E}-11$ & - & & $2.88 \mathrm{E}-06$ & 3.49E-07 & 8.25 \\
\hline BR3 & 42.0 & $1.09 \mathrm{E}-12$ & $1.11 \mathrm{E}-12$ & 0.98 & 2.19E-06 & $1.35 \mathrm{E}-06$ & 1.62 \\
\hline BR30 & 33.7 & $8.79 \mathrm{E}-12$ & - & & $3.07 \mathrm{E}-06$ & $6.73 \mathrm{E}-07$ & 4.56 \\
\hline SA & & 6.07E-17 & $1.66 \mathrm{E}-16$ & 0.37 & $2.55 \mathrm{E}-12$ & $2.42 \mathrm{E}-12$ & 1.05 \\
\hline SB1 & 6.9 & $1.39 \mathrm{E}-15$ & $1.25 \mathrm{E}-15$ & 1.11 & 4.10E-10 & - & \\
\hline SB2 & 6.9 & 2.03E-15 & 2.24E-15 & 0.91 & $6.82 \mathrm{E}-10$ & 3.64E-10 & 1.87 \\
\hline SC2 & 2.6 & $1.77 \mathrm{E}-16$ & 1.12E-16 & 1.58 & & - & \\
\hline SC3 & 2.6 & $1.94 \mathrm{E}-15$ & - & & 3.30E-11 & $5.58 \mathrm{E}-12$ & 5.91 \\
\hline SC4 & 2.6 & $2.06 \mathrm{E}-16$ & 1.12E-16 & 1.84 & & - & \\
\hline SC4 & 2.6 & $2.25 \mathrm{E}-16$ & 2.06E-16 & 1.09 & & - & \\
\hline SC5 & 2.6 & 6.13E-17 & 3.51E-17 & 1.75 & & - & \\
\hline SC6 & 2.6 & $5.41 \mathrm{E}-17$ & 3.83E-17 & 1.41 & & - & \\
\hline SC7 & 2.6 & $3.51 E-16$ & $1.64 \mathrm{E}-16$ & 2.14 & $1.45 \mathrm{E}-11$ & 8.40E-12 & 1.73 \\
\hline SC8 & 2.6 & $5.03 E-17$ & 3.30E-17 & 1.52 & & - & \\
\hline SC8 & 2.6 & 5.92E-17 & 3.93E-17 & 1.51 & & - & \\
\hline SW1 & 15.9 & 4.17E-16 & $9.41 E-15$ & 0.04 & & - & \\
\hline SW2 & 15.9 & $5.05 E-16$ & 4.92E-16 & 1.03 & & - & \\
\hline SW3 & 15.9 & $1.53 \mathrm{E}-14$ & - & & 3.10E-10 & 7.07E-11 & 4.38 \\
\hline SW4 & 15.9 & $1.47 \mathrm{E}-16$ & 1.14E-16 & 1.29 & & - & \\
\hline SW5 & 15.9 & $1.60 \mathrm{E}-16$ & - & & & 1.92E-09 & \\
\hline SW6 & 15.9 & $6.03 \mathrm{E}-15$ & $8.50 \mathrm{E}-15$ & 0.71 & $3.70 \mathrm{E}-10$ & $1.81 \mathrm{E}-10$ & 2.04 \\
\hline Oxypol I678L-05 & 17.4 & $3.07 \mathrm{E}-14$ & $5.35 \mathrm{E}-14$ & 0.57 & $5.88 \mathrm{E}-09$ & 2.17E-09 & 2.71 \\
\hline Oxypol I678L-06 & 17.4 & $2.50 \mathrm{E}-13$ & - & & $3.20 \mathrm{E}-08$ & 9.93E-09 & 3.22 \\
\hline Oxypol I678L-10 & 16.1 & $5.49 \mathrm{E}-14$ & $2.02 \mathrm{E}-13$ & 0.27 & 7.33E-09 & 2.60E-09 & 2.82 \\
\hline Oxypol I678L-11 & 16.1 & $2.93 E-14$ & $4.46 \mathrm{E}-14$ & 0.66 & 4.48E-09 & 1.84E-09 & 2.43 \\
\hline Oxypol I678L-12 & 16.3 & $4.85 E-14$ & $9.63 E-14$ & 0.50 & 7.34E-09 & 2.93E-09 & 2.51 \\
\hline PH 1431-05 & 12.7 & $6.04 \mathrm{E}-13$ & - & & 5.93E-08 & 2.04E-08 & 2.91 \\
\hline PH 1431-06 & 13.4 & $2.85 \mathrm{E}-12$ & $4.86 \mathrm{E}-12$ & 0.59 & 3.90E-07 & 1.93E-07 & 2.02 \\
\hline PH 1866-01 & 9.4 & 4.76E-13 & $1.51 \mathrm{E}-12$ & 0.32 & $6.14 \mathrm{E}-08$ & $2.32 \mathrm{E}-08$ & 2.65 \\
\hline PH 1866-02 & 9.2 & $5.22 \mathrm{E}-13$ & $1.40 \mathrm{E}-12$ & 0.37 & $6.44 \mathrm{E}-08$ & $2.56 \mathrm{E}-08$ & 2.52 \\
\hline PH 1866-03 & 9.1 & $5.01 \mathrm{E}-13$ & 1.19E-12 & 0.42 & 7.38E-08 & 2.94E-08 & 2.51 \\
\hline Whipox W979-01 & 26.9 & $9.11 \mathrm{E}-15$ & - & & $8.80 \mathrm{E}-10$ & $2.95 \mathrm{E}-10$ & 2.98 \\
\hline Whipox W979-02 & 26.5 & 8.34E-15 & $1.47 \mathrm{E}-13$ & 0.06 & $9.34 \mathrm{E}-10$ & $3.20 \mathrm{E}-10$ & 2.92 \\
\hline Whipox W979-03 & 26.9 & $4.28 \mathrm{E}-15$ & $6.18 \mathrm{E}-15$ & 0.69 & $6.20 \mathrm{E}-10$ & $2.55 \mathrm{E}-10$ & 2.43 \\
\hline Whipox WA10-01 & 34.4 & $2.88 \mathrm{E}-14$ & $3.78 \mathrm{E}-14$ & 0.76 & 1.07E-08 & 4.95E-08 & 0.22 \\
\hline Whipox WA10-02 & 31.0 & $9.11 \mathrm{E}-15$ & $9.69 \mathrm{E}-15$ & 0.94 & $1.13 \mathrm{E}-08$ & 5.96E-09 & 1.90 \\
\hline Whipox WA10-03 & 35.0 & $5.70 \mathrm{E}-14$ & $6.18 \mathrm{E}-15$ & 9.22 & $1.70 \mathrm{E}-08$ & 6.93E-09 & 2.45 \\
\hline
\end{tabular}


Table 5. Improvement of ESA/DLR behavior with DLR in-house code compared to Excel software for a selection of samples.

\begin{tabular}{|c|c|c|c|c|c|c|c|c|c|c|c|}
\hline & \multirow[b]{2}{*}{$\begin{array}{c}\text { Open } \\
\text { porosity } \\
(\%)\end{array}$} & \multicolumn{5}{|c|}{ Darcian permeability $\left(\mathrm{m}^{2}\right)$} & \multicolumn{5}{|c|}{ Forchheimer's permeability (m) } \\
\hline & & $\begin{array}{c}\text { ISO } \\
\text { Method }\end{array}$ & $\begin{array}{l}\mathrm{P}^{2} \text { Method } \\
\text { (Excel } \\
\text { software) }\end{array}$ & $\begin{array}{l}\mathrm{P}^{2} \text { Method } \\
\text { (DLR in- } \\
\text { house } \\
\text { code) }\end{array}$ & $\begin{array}{l}\text { Methods } \\
\text { ratio } \\
\text { (Excel) }\end{array}$ & $\begin{array}{c}\text { Methods } \\
\text { ratio (DLR } \\
\text { code) }\end{array}$ & $\begin{array}{c}\text { ISO } \\
\text { Method }\end{array}$ & $\begin{array}{l}\mathrm{P}^{2} \text { Method } \\
\text { (Excel } \\
\text { software) }\end{array}$ & $\begin{array}{l}\mathrm{P}^{2} \text { Method } \\
\text { (DLR in- } \\
\text { house } \\
\text { code) }\end{array}$ & $\begin{array}{c}\text { Methods } \\
\text { ratio } \\
\text { (Excel) }\end{array}$ & $\begin{array}{c}\text { Methods } \\
\text { ratio (DLR } \\
\text { code) }\end{array}$ \\
\hline BR30 & 33.7 & 8.79E-12 & - & $1.546 \mathrm{E}-11$ & & 0.57 & 3.07E-06 & $6.73 E-07$ & 2.095E-06 & 4.56 & 1.47 \\
\hline Oxypol I678L-05 & 17.4 & 3.07E-14 & $5.35 \mathrm{E}-14$ & 3.116E-14 & 0.57 & 0.99 & 5.88E-09 & 2.17E-09 & 6.077E-09 & 2.71 & 0.97 \\
\hline Oxypol I678L-06 & 17.4 & $2.50 \mathrm{E}-13$ & - & $2.51 \mathrm{E}-13$ & & 0.99 & 3.20E-08 & 9.93E-09 & 3.24E-08 & 3.22 & 0.99 \\
\hline PH 1431-05 & 12.7 & 6.04E-13 & - & $6.061 \mathrm{E}-13$ & & 1.00 & 5.93E-08 & 2.04E-08 & 6.009E-08 & 2.91 & 0.99 \\
\hline $\mathrm{PH} 1431-06$ & 13.4 & 2.85E-12 & $4.86 \mathrm{E}-12$ & $2.786 \mathrm{E}-12$ & 0.59 & 1.02 & 3.90E-07 & 1.93E-07 & 4.165E-07 & 2.02 & 0.94 \\
\hline
\end{tabular}


Table 6. PRISME and DLR values of permeabilities with respective methods.

\begin{tabular}{|c|c|c|c|c|c|c|c|}
\hline \multirow[b]{2}{*}{$\begin{array}{c}\text { Sample } \\
\text { designation }\end{array}$} & \multirow[b]{2}{*}{$\begin{array}{l}\text { Diameter of } \\
\text { cross section } \\
\text { (DLR) }\end{array}$} & \multicolumn{2}{|c|}{ PRISME bench } & \multicolumn{2}{|c|}{ DLR bench } & \multirow[b]{2}{*}{$\begin{array}{l}\text { PRISME/DLR } \\
\text { KD values ratio }\end{array}$} & \multirow[b]{2}{*}{$\begin{array}{l}\text { PRISME/DLR } \\
\text { KF values ratio }\end{array}$} \\
\hline & & $\mathrm{KD}\left(\mathrm{m}^{2}\right)$ & $\mathrm{KF}(\mathrm{m})$ & $\mathrm{KD}\left(\mathrm{m}^{2}\right)$ & $\mathrm{KF}(\mathrm{m})$ & & \\
\hline SS3new & $30 \mathrm{~mm}$ & $2.27 \mathrm{E}-13$ & $5.63 E-07$ & $2.21 \mathrm{E}-13$ & $2.55 \mathrm{E}-07$ & 1.03 & 2.21 \\
\hline SS3old & $30 \mathrm{~mm}$ & & & 8.85E-14 & 2.56E-08 & 2.57 & \\
\hline SS3-2 & $30 \mathrm{~mm}$ & $1.16 \mathrm{E}-13$ & $1.59 \mathrm{E}-07$ & $1.35 \mathrm{E}-13$ & 1.14E-07 & 0.86 & 1.40 \\
\hline BR30 & $30 \mathrm{~mm}$ & 8.79E-12 & 3.07E-06 & 8.83E-11 & 1.65E-05 & 0.10 & 0.19 \\
\hline SB1 & $16 \mathrm{~mm}$ & $139 \mathrm{~F}-15$ & & $1.78 \mathrm{E}-14$ & 2.83E-10 & 0.08 & 1.45 \\
\hline SB1 & $30 \mathrm{~mm}$ & 1.39E-15 & 4.10E-10 & 5.07E-15 & $2.29 E-11$ & 0.27 & \\
\hline $\mathrm{SC} 2$ & $16 \mathrm{~mm}$ & 197 & & 2.49E-14 & 1.17E-10 & 0.01 & \\
\hline $\mathrm{SC} 2$ & $30 \mathrm{~mm}$ & $1.7 / \mathrm{E}-16$ & & 7.09E-15 & $9.44 \mathrm{E}-12$ & 0.02 & \\
\hline SC4 & $16 \mathrm{~mm}$ & 2.06E-16 & & 2.63E-16 & 6.54E-12 & 0.78 & \\
\hline $\mathrm{SC} 4$ & $30 \mathrm{~mm}$ & $2.25 E-16$ & & $7.49 \mathrm{E}-17$ & $5.29 E-13$ & 3.01 & \\
\hline SC5 & $16 \mathrm{~mm}$ & $612=17$ & & $1.71 \mathrm{E}-16$ & & 0.36 & \\
\hline SC5 & $30 \mathrm{~mm}$ & 6.13E-1/ & & 4.87E-17 & & 1.26 & \\
\hline SC6 & $16 \mathrm{~mm}$ & $541 \mathrm{E}-17$ & & $1.26 \mathrm{E}-16$ & $1.62 \mathrm{E}-12$ & 0.43 & \\
\hline SC6 & $30 \mathrm{~mm}$ & $3.41 \mathrm{~L}-1 /$ & & 3.59E-17 & $1.31 \mathrm{E}-13$ & 1.51 & \\
\hline SC8 & $16 \mathrm{~mm}$ & 5.03E-17 & & $2.33 E-16$ & 7.01E-13 & 0.22 & \\
\hline SC8 & $30 \mathrm{~mm}$ & $5.92 \mathrm{E}-17$ & & 6.64E-17 & 5.67E-14 & 0.89 & \\
\hline
\end{tabular}


Table 7. PRISME and ATLLAS values of permeabilities with respective methods.

\begin{tabular}{|c|c|c|c|c|c|c|c|c|}
\hline \multirow[b]{2}{*}{ Sample designation } & \multicolumn{2}{|c|}{ PRISME bench } & \multicolumn{2}{|c|}{ ATLLAS values } & \multirow[b]{2}{*}{$\begin{array}{l}\text { PRISME/ATLLAS } \\
\text { KD values ratio }\end{array}$} & \multirow[b]{2}{*}{$\begin{array}{l}\text { PRISME/ATLLAS } \\
\text { KF values ratio }\end{array}$} & \multicolumn{2}{|c|}{$\begin{array}{c}\text { Ratio between extremum } \\
\text { ATLLAS values }\end{array}$} \\
\hline & $\mathrm{KD}\left(\mathrm{m}^{2}\right)$ & $\mathrm{KF}(\mathrm{m})$ & $\mathrm{KD}\left(\mathrm{m}^{2}\right)$ & $\mathrm{KF}(\mathrm{m})$ & & & for KD & for KF \\
\hline Oxypol I678L-06 & $2.46 \mathrm{E}-13$ & $3.25 E-08$ & $\begin{array}{l}3.74 \mathrm{E}-14 \\
7.37 \mathrm{E}-14\end{array}$ & $\begin{array}{l}9.69 \mathrm{E}-09 \\
1.52 \mathrm{E}-08\end{array}$ & $\begin{array}{l}6.57 \\
3.34\end{array}$ & $\begin{array}{l}3.36 \\
2.14\end{array}$ & 1.97 & 1.57 \\
\hline Oxypol 1678L-05 & $4.55 \mathrm{E}-14$ & 5.87E-09 & & & 10.95 & 1.05 & & \\
\hline Oxypol I678L-10 & $5.49 \mathrm{E}-14$ & 7.33E-09 & & & 13.23 & 1.31 & & \\
\hline Oxypol I678L-11 & $5.10 \mathrm{E}-14$ & 4.45E-09 & 4.15E-15 & 5.59E-09 & 12.29 & 0.80 & & \\
\hline Oxypol I678L-12 & $4.85 \mathrm{E}-14$ & 7.34E-09 & & & 11.69 & 1.31 & & \\
\hline PH 1431-05 & $6.04 \mathrm{E}-13$ & 5.93E-08 & & & 7.65 & 3.57 & & \\
\hline PH 1431-05(glued) & $2.45 \mathrm{E}-13$ & 3.43E-08 & $\begin{array}{l}7.89 \mathrm{E}-14 \\
1.15 \mathrm{E}-13\end{array}$ & $\begin{array}{l}1.66 \mathrm{E}-08 \\
1.69 \mathrm{E}-08\end{array}$ & $\begin{array}{l}5.25 \\
3.11 \\
2.13\end{array}$ & $\begin{array}{l}3.51 \\
2.07 \\
2.03\end{array}$ & 1.46 & 1.02 \\
\hline PH 1431-06 & $2.85 \mathrm{E}-12$ & $3.90 \mathrm{E}-07$ & $\begin{array}{l}4.51 \mathrm{E}-13 \\
5.54 \mathrm{E}-13\end{array}$ & $\begin{array}{l}1.75 \mathrm{E}-07 \\
2.42 \mathrm{E}-07\end{array}$ & $\begin{array}{l}6.33 \\
5.15\end{array}$ & $\begin{array}{l}2.23 \\
1.61\end{array}$ & 1.23 & 1.38 \\
\hline
\end{tabular}


Figure 1. SS3-2 sample permeation data plotted in the form of ISO4022 method (a) and of $\mathrm{P}^{2}$ method (b).

Figure 2. Mounting of the sample represented by a schematic of the permeation cell with sensors.

Figure 3. DLR experimental setup

Figure 4. Pictures of porous media with corresponding denomination (SS: Stainless Steel and BR: Bronze with corresponding Poral class).

Figure 5. Ratio of Darcian term found with each method.

Figure 6. Effect of the open porosity and material nature on the adequacy between both methods.

Figure 7. Ratio of Forchheimer's term found with each method.

Figure 8. Limitation of Excel software for KF determination (a) and the improved behavior based on the DLR in-house code (b).

Figure 9. Specific device for thin samples to be tested with DLR bench.

Figure 10. PH 1431-05 sample before and after being glued to limit the transverse permeation and favors the longitudinal permeation. 

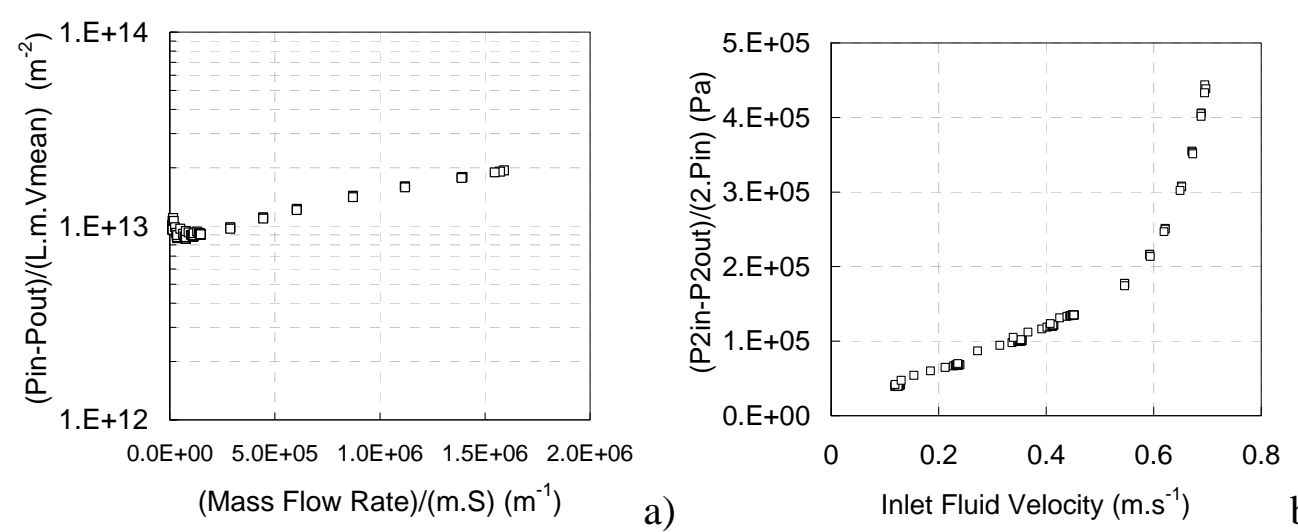

Figure 1. SS3-2 sample permeation data plotted in the form of ISO method (a) and of $\mathbf{P}^{2}$ method (b). 


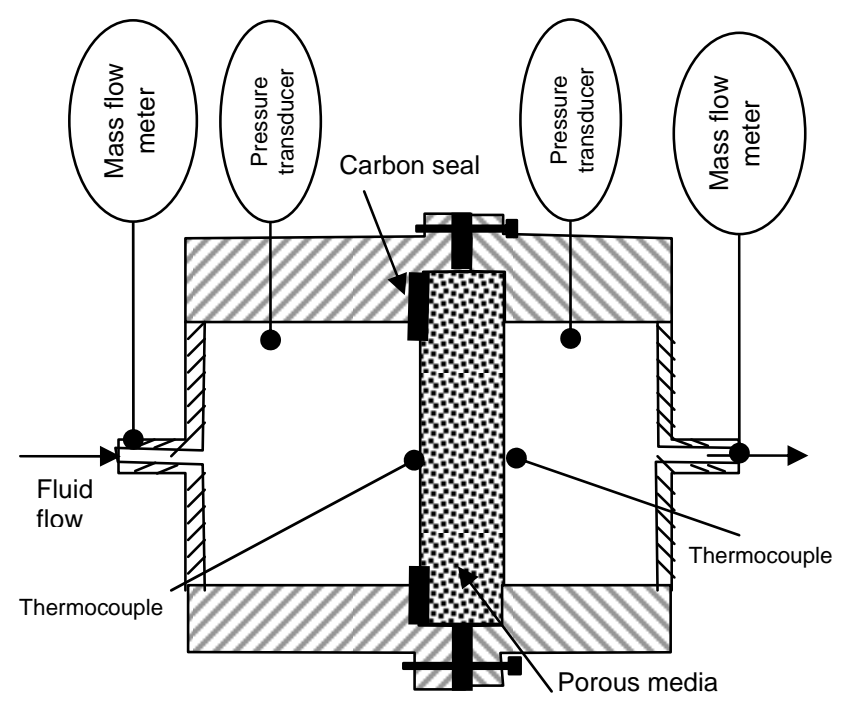

Figure 2. Mounting of the sample represented by a schematic of the permeation cell with sensors. 


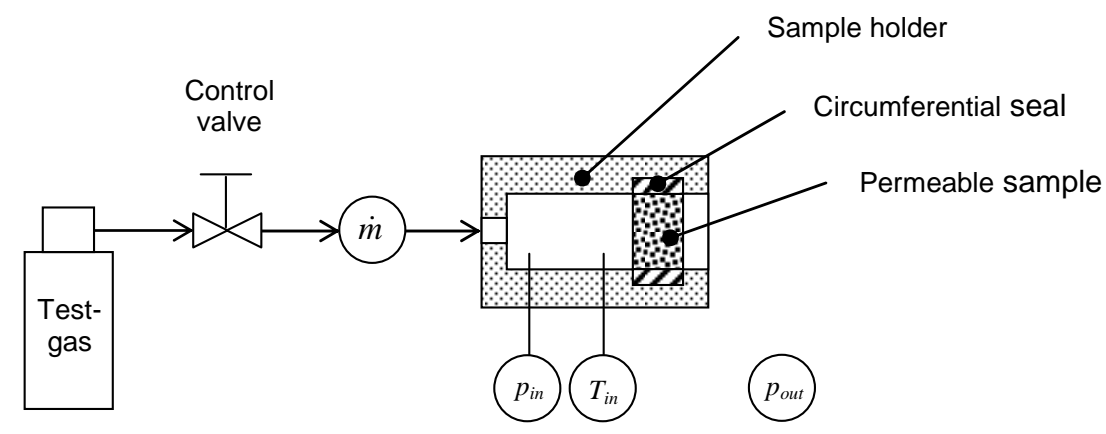

Figure 3. DLR experimental setup 

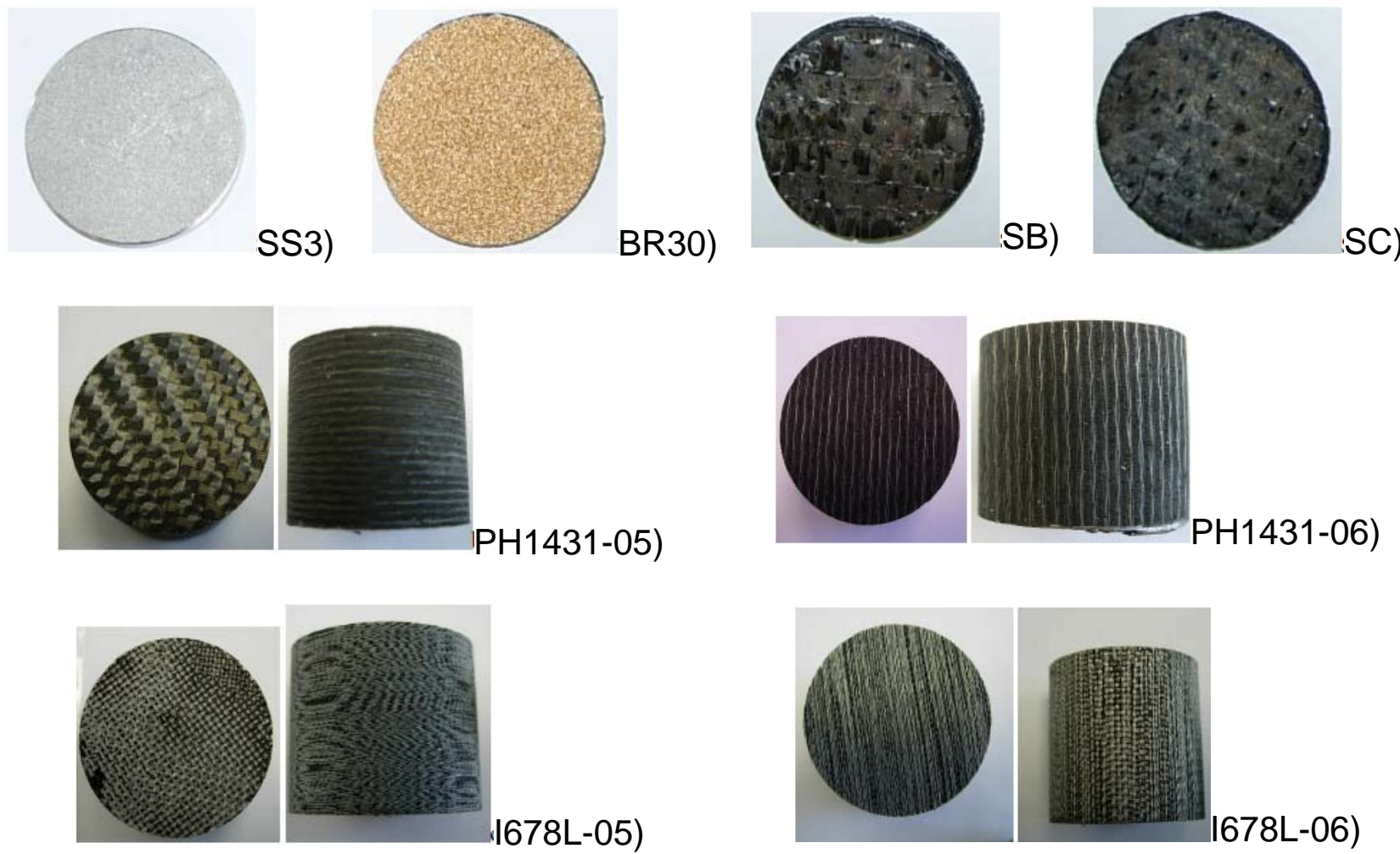

Figure 4. Pictures of porous media with corresponding denomination (SS: Stainless Steel and BR: Bronze with corresponding Poral class). 


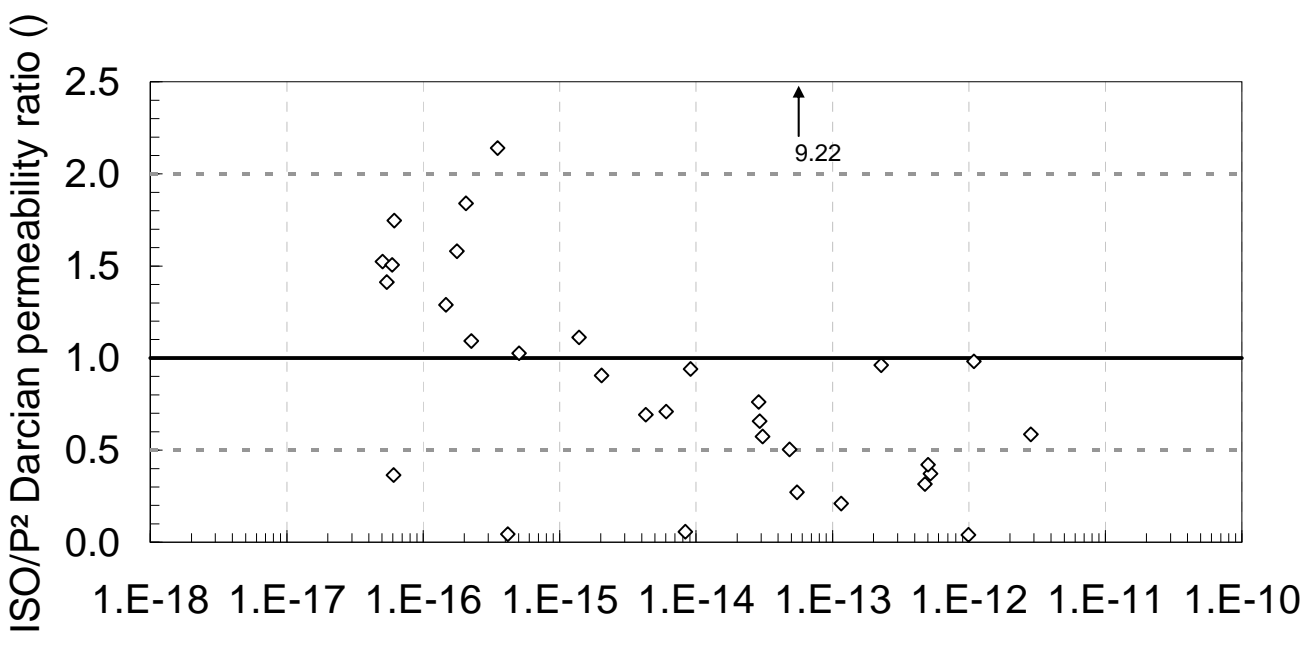

Darcian permeability by ISO method $\left(\mathrm{m}^{2}\right)$

Figure 5. Ratio of Darcian term found with each method. 


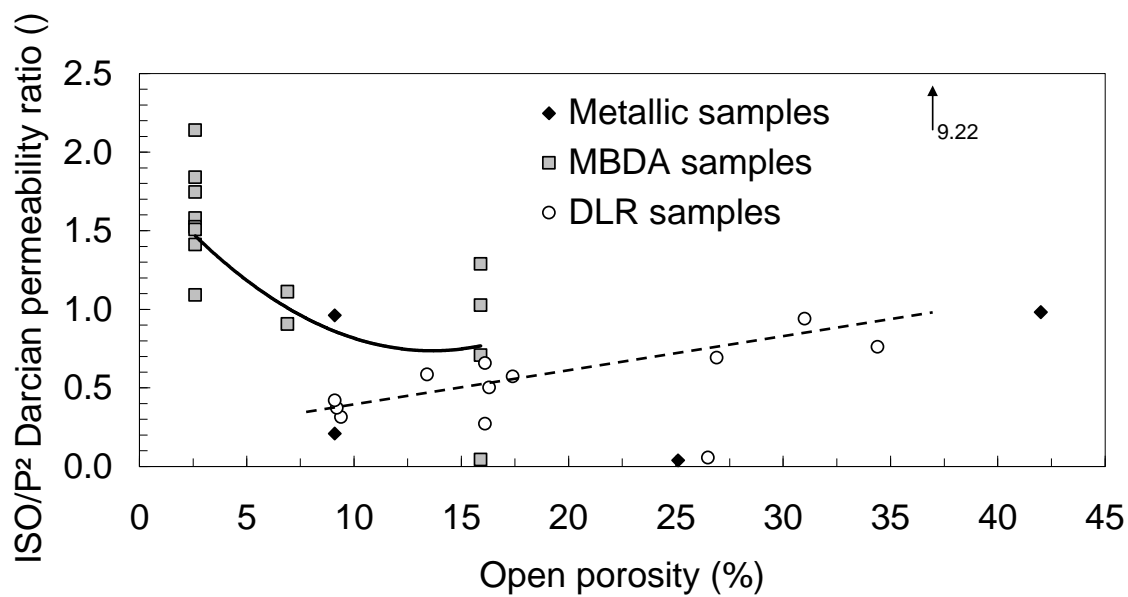

Figure 6. Effect of the open porosity and material nature on the adequacy between both methods. 


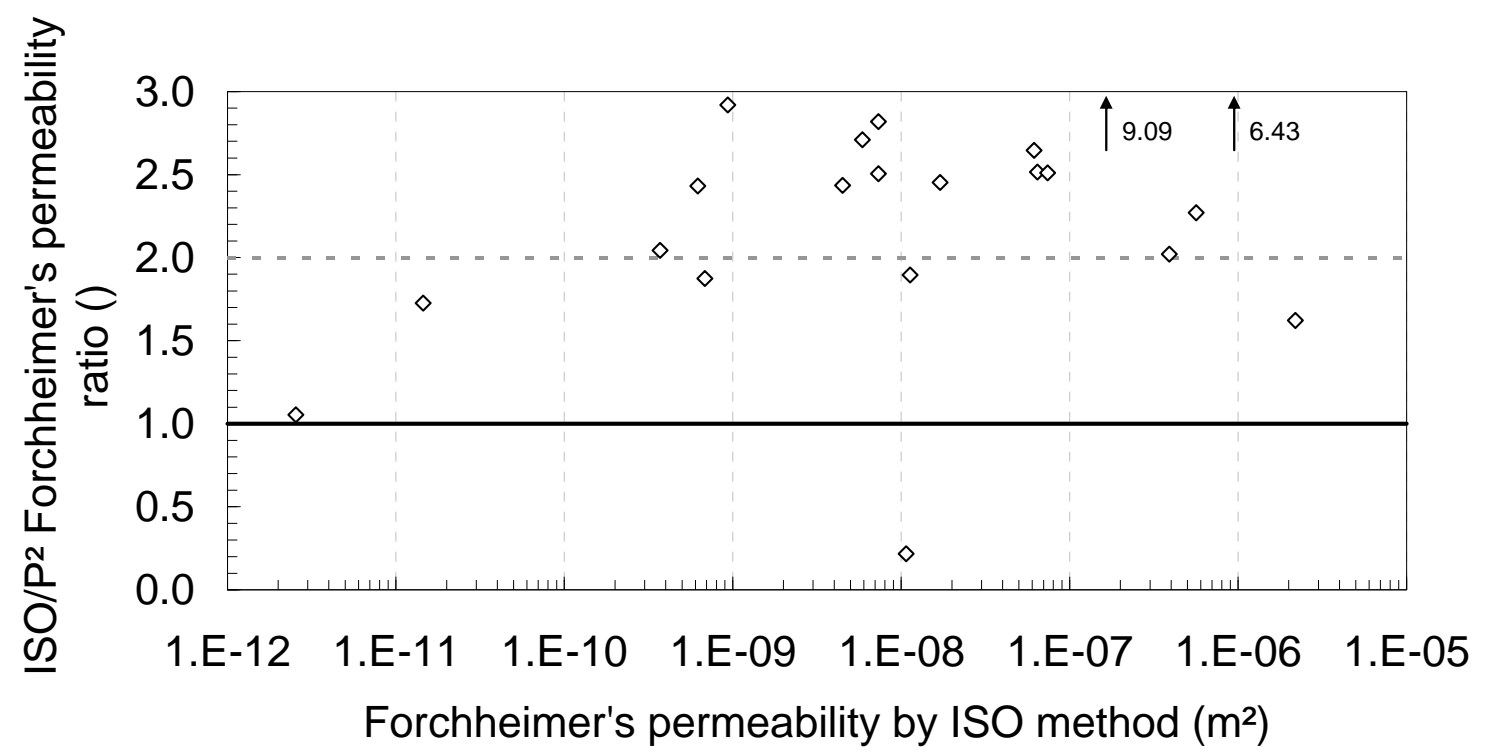

Figure 7. Ratio of Forchheimer's term found with each method. 


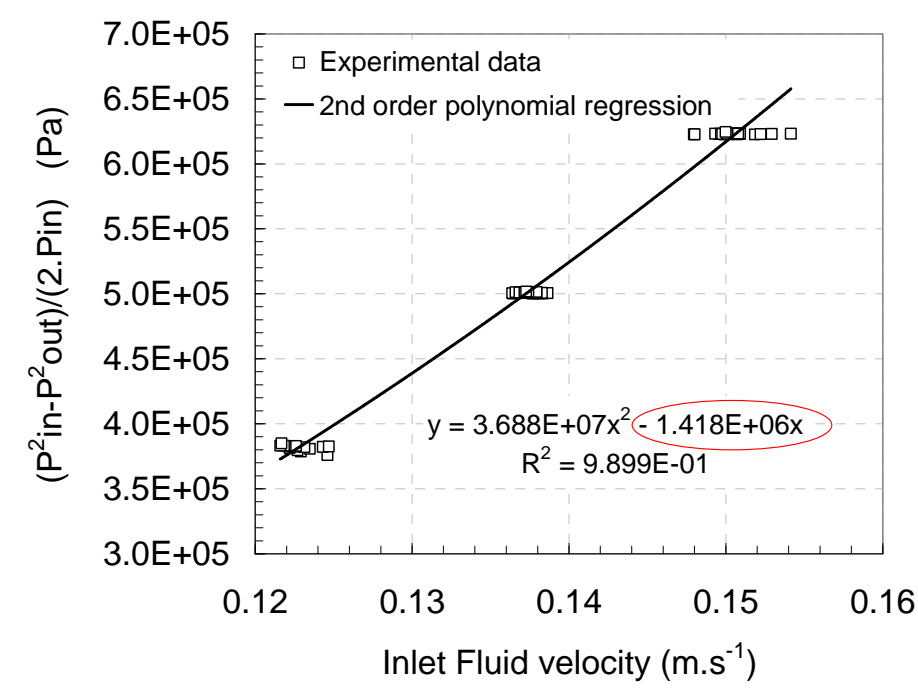

a)

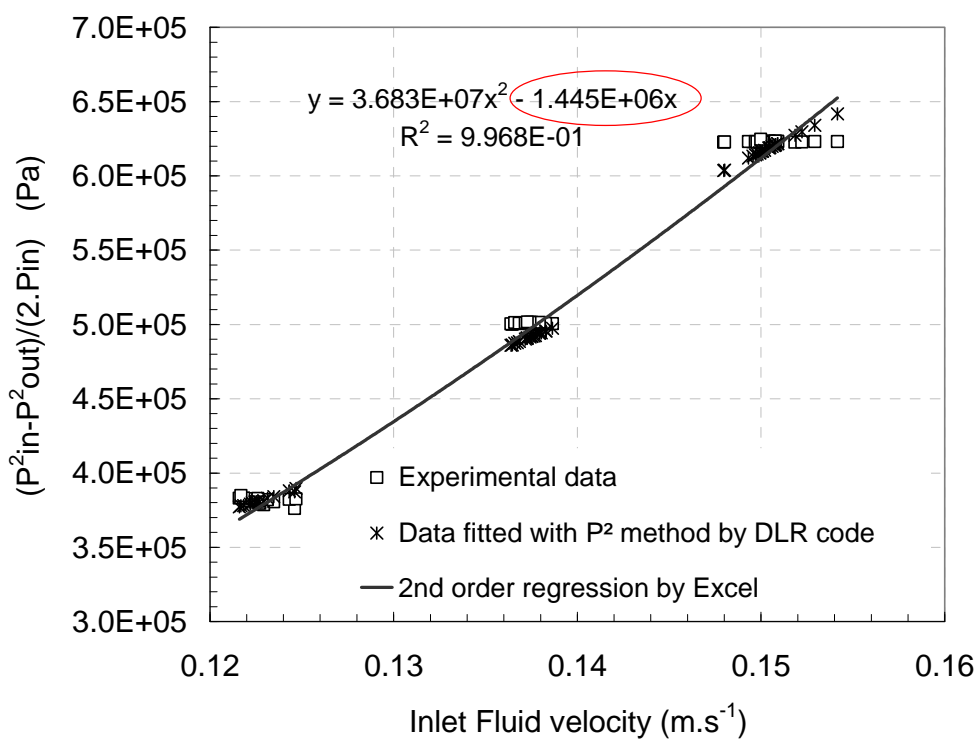

b)

Figure 8. Limitation of Excel software for $K_{F}$ determination (a) and the improved behavior based on the DLR in-house code (b). 


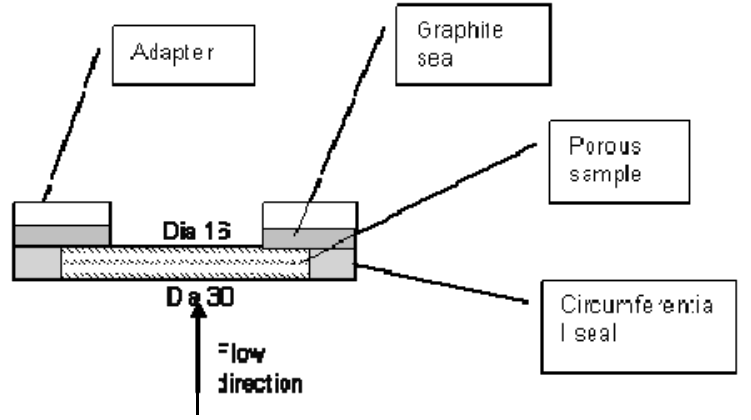

Figure 9. Specific device for thin samples to be tested with DLR bench. 


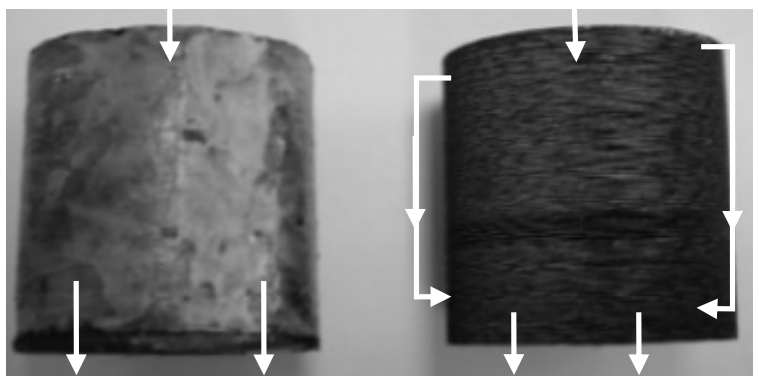

With glue

Reference

Figure 10. PH 1431-05 sample before and after being glued to limit the transverse permeation and favors the longitudinal permeation. 